University of Nebraska - Lincoln

DigitalCommons@University of Nebraska - Lincoln

\title{
The effects of insecticide dose and herbivore density on tri- trophic effects of thiamethoxam in a system involving wheat, aphids, and ladybeetles
}

\author{
Michael M. Bredeson \\ Department of Biology and Microbiology, South Dakota State University; USDA-ARS, North Central \\ Agricultural Research Laboratory \\ R Neil Reese \\ Department of Biology and Microbiology, South Dakota State University \\ Jonathan G. Lundgren \\ USDA-ARS, North Central Agricultural Research Laboratory, jonathan.lundgren@ars.usda.gov
}

Follow this and additional works at: https://digitalcommons.unl.edu/usdaarsfacpub

Part of the Environmental Studies Commons

Bredeson, Michael M.; Reese, R Neil; and Lundgren, Jonathan G., "The effects of insecticide dose and herbivore density on tri-trophic effects of thiamethoxam in a system involving wheat, aphids, and ladybeetles" (2015). Publications from USDA-ARS / UNL Faculty. 1496.

https://digitalcommons.unl.edu/usdaarsfacpub/1496

This Article is brought to you for free and open access by the U.S. Department of Agriculture: Agricultural Research Service, Lincoln, Nebraska at DigitalCommons@University of Nebraska - Lincoln. It has been accepted for inclusion in Publications from USDA-ARS / UNL Faculty by an authorized administrator of DigitalCommons@University of Nebraska - Lincoln. 


\title{
The effects of insecticide dose and herbivore density on tri-trophic effects of thiamethoxam in a system involving wheat, aphids, and ladybeetles
}

\author{
Michael M. Bredeson ${ }^{\text {a, b }}{ }^{\text {, R. Neil Reese }}{ }^{\text {a }}$, Jonathan G. Lundgren ${ }^{\text {b, * }}$ \\ a Department of Biology and Microbiology, South Dakota State University, Brookings, SD, 57007, USA \\ ${ }^{\mathrm{b}}$ USDA-ARS, North Central Agricultural Research Laboratory, Brookings, SD, 57006, USA
}

\section{A R T I C L E I N F O}

\section{Article history:}

Received 16 July 2014

Received in revised form

16 December 2014

Accepted 19 December 2014

Available online 27 December 2014

\section{Keywords:}

Non-target effects

Clothianidin

Coleomegilla maculata

Predators

Rhophalosiphum padi

Systemic insecticide

Tri-trophic interactions

Wheat

\begin{abstract}
A B S T R A C T
We assess how herbivore density and insecticide dose affects the tri-trophic interactions among thiamethoxam-treated wheat (Triticum sp.), Rhophalosiphum padi and the predatory Coleomegilla maculata DeGeer. In the first experiment 2nd and 4th instar C. maculata were fed aphids reared for $24 \mathrm{~h}$ on wheat plants treated with sub-lethal thiamethoxam soil drenches to assess the effect of insecticidal dose on the predator. In the second experiment a constant, sub-lethal thiamethoxam soil drench was used on wheat plants, but the plants were infested with different densities of aphids. Aphids from each density treatment were then fed to $C$. maculata 2 nd instars. Insecticide levels within wheat and aphid tissues were quantified using a competitive ELISA. In experiment one, 4th instars of $C$. maculata displayed no negative effects after consuming aphids from treated plants. However, 2nd instars of $C$. maculata ate more treated aphids than untreated aphids and larval development times varied between the untreated larvae and those receiving the low dose of the insecticide. In experiment two, the 2 nd instar C. maculata displayed slower walking speeds after consuming aphids from low aphid density plants. Thiamethoxam within wheat tissue was found at higher levels with increasing dose. This insecticide was also found at higher levels in wheat plants with the lowest aphid density. Clothianidin, a toxic metabolite of thiamethoxam, was found in aphids that had fed on thiamethoxam-treated wheat, but no differences between treatments were observed. The neonicotinoid treatment altered the quality of $R$. padi as prey for 2nd instar C. maculata, but this depended on the aphid infestation level on the plants. In addition to revealing a potential deleterious effect of thiamethoxam systemic insecticides in wheat, our assays provide insight into the design and interpretation of toxicity assays involving systemic neonicotinoids and herbivores.
\end{abstract}

Published by Elsevier Ltd.

\section{Introduction}

Since their introduction in 1991, neonicotinoid insecticides have become commonly used in many agricultural settings to control pest insects (Nauen and Denholm, 2005). Neonicotinoids act as agonists to the acetylcholine receptors within the nervous system of an animal, mimicking the action of naturally produced acetylcholine (Jeschke et al., 2013), a neurotransmitter which allows action potentials to move from nerve cell to nerve cell. The

\footnotetext{
* Corresponding author. USDA-ARS, NCARL, 2923 Medary Avenue, Brookings, SD, 57006, USA.

E-mail addresses: jonathan.lundgren@ars.usda.gov, jgl.entomology@gmail.com (J.G. Lundgren).
}

overstimulation of nerve cells due to neonicotinoid insecticides can cause paralysis (Girolami et al., 2009) and death (Iwasa et al., 2004) in insects. The popularity of neonicotinoid use has risen in part because of the diverse means by which the chemicals can be applied. This class of insecticides can be applied as granules in the soil (Lanka et al., 2014), foliar sprays (Juraske et al., 2009), soil drenches (Stoner and Eitzer, 2012), tree injections (Cowles et al., 2006) and topically to animals (Dryden et al., 2011). However, the most widespread application method of neonicotinoids has been as seed treatments that protect plants from herbivory (Jeschke et al., 2010).

Although the threat against beneficial insects is reduced by using systemic insecticides compared to broad spectrum insecticidal sprays, there is evidence that systemically treated plants do in 
fact harm beneficial insects through a number of pathways (Lundgren, 2009). For example, Moser and Obrycki (2009) exposed Asian ladybeetle (Harmonia axyridis Pallas (Coleoptera: Coccinellidae)) larvae to corn seedlings grown from seed treated with neonicotinoids. The ladybeetle larvae expressed neurotoxic symptoms such as trembling, paralysis and loss of coordination in $72 \%$ of cases, presumably the result of the observed and quantified facultative herbivory (Moser and Obrycki, 2009). In another toxicology study, Rogers et al. (2007) confined Chrysoperla carnea (Neuroptera: Chrysopidae) adults to the flowers of neonicotinoid treated Fagopyrum esculentum and Asclepias curassavica where they consumed the nectar. Survival of C. carnea was significantly reduced in the insecticide treatment after $10 \mathrm{~d}$ compared to an untreated control group; the authors concluded that survival was diminished due to the ingestion of nectar containing neonicotinoid insecticide (Rogers et al., 2007).

Besides direct mortality of beneficial insects resulting from the use of systemic neonicotinoids, sub-lethal concentrations of insecticide within plants can act as one of a suite of stressors that result in diminished fitness of non-target species. Consequences of ingesting sub-lethal concentrations of insecticides can include reduced fecundity (Shi et al., 2011), lowered mobility (Scholer and Krischik, 2014), loss of orientation abilities (Fischer et al., 2014), limited overwintering survivability (Grewal et al., 2001) and reduced foraging capacity (Schneider et al., 2012). The sub-lethal effects of neonicotinoids can potentially reduce the efficiency of predator and parasitoid communities, threatening biotic resistance to pest proliferation (Seagraves and Lundgren, 2012).

Predation on crop pests by predators and parasitoids provides not only environmental benefits, but also has tangible economic value to land owners, and is an important component of Integrated Pest Management (IPM) (Zhang and Swinton, 2009). Plant incorporated systemic insecticides may affect non-target predators through various trophic pathways, primarily considered bi-trophic (Lundgren, 2009), or tri-trophic (prey-mediated) effects (Birch et al., 1999). Beneficial insects are exposed to systemic insecticides through omnivory on non-prey foods such as vegetative plant tissue (Moser and Obrycki, 2009), pollen (Cresswell, 2011; Dively and Kamel, 2012), guttation fluid (Girolami et al., 2009), floral (Krischik et al., 2007) or extra-floral nectar (Stapel et al., 2000). Predators can also be adversely affected by an insecticide if their herbivorous prey contains the toxin or the quality of the prey is lessened by ingesting insecticide-containing plant tissues (Dutton et al., 2002). Documenting the trophic relationships between systemically treated-plants, pests and beneficial insects is important for understanding the compatibility of systemic insecticides within IPM systems.

Wheat is a crop of significant importance worldwide; 18.5 million ha of wheat was harvested in the United States in 2013 alone (NASS, 2014). Rhopalosiphum padi (L.) (bird cherry-oat aphid, Hemiptera: Aphididae) is a common pest of wheat in the U.S. and worldwide, causing significant damage resulting from feeding and transmitting viruses (Jiménez-Martínez et al., 2004). Neonicotinoid seed treatments are highly water soluble (Maienfisch et al., 2001) and are readily transported through both xylem and phloem, making this class of insecticides and method of application well adapted for the control of phloem feeding insects, like aphids (Magalhaes et al., 2009), in a variety of crops including wheat (Gray et al., 1996).

Members of the Coccinellidae family have historically been used frequently and effectively as a useful tool in biological control programs to limit pest arthropod herbivory (Biddinger et al., 2009; Weber and Lundgren, 2009), especially from aphids (Obrycki et al., 2009). One species of Coccinellidae, Coleomegilla maculata DeGeer (Coleoptera: Coccinellidae), is a predator of $R$. padi in wheat (Elliott et al., 1999) and in other crops including corn (Lundgren and Wiedenmann, 2005), thus C. maculata could potentially be affected tri-trophically by aphids feeding on systemically treated wheat. Sublethal levels of neonicotinoid insecticides can be found in crops either as the seed treatment dissipates over the season (McCornack and Ragsdale, 2006; Seagraves and Lundgren, 2012), or through uptake of residual insecticides found in the soil from previous insecticide applications. Here we examine the tri-trophic interactions among wheat plants containing sublethal doses of thiamethoxam, aphids, and the predatory C. maculata. Specifically, we examined how insecticide dose in the wheat plants and aphid densities on the wheat plants interact to affect $C$. maculata larvae.

\section{Methods}

\subsection{Wheat, ladybeetle and aphid bioassays}

\subsubsection{Insects and plants}

A C. maculata DeGeer colony was established from individuals collected from a corn field near Brookings, SD, USA (44.3114 ${ }^{\circ} \mathrm{N}$, $96.7981^{\circ} \mathrm{W}$ ), and was raised for three generations (approximately $15 \mathrm{mo}$ ) in the laboratory. The colony was maintained on a semiartificial diet (Lundgren's Super C. mac Diet, (Lundgren et al., 2011)) and honey. The beetles were raised at $26.5{ }^{\circ} \mathrm{C}$ with $16: 8 \mathrm{~h}$ (L:D; light: dark) photoperiod. The $R$. padi colony was established from individuals collected in Hays, Kansas. Aphids were reared on barley plants (Hordeum vulgare L. var. Robust, Poales: Poaceae) at $19{ }^{\circ} \mathrm{C}$ and 16:8 h L:D. Wheat (Triticum aestivum L., Poales: Poaceae) was produced individually in planting cones (Ray Leach Conetainer cells, SC10 Super, Tangent, OR, USA, 97389) filled with potting soil mix (Miracle-Gro ${ }^{\circledR}$ MicroMax ${ }^{\circledR}$, Marysville, OH. 43041). Each plant was given $20 \mathrm{~mL}$ of water daily and grown in a greenhouse set at $24^{\circ} \mathrm{C}$ and 16:8 L:D (Greenhouse lights: $\mathrm{GE}^{\circledR}$ Lucalox LU1000, and GE ${ }^{\circledR}$ MVR1000/U, General Electric Company ${ }^{\circledR}$, Fairfield, Ct, USA, 06828).

\subsubsection{Experiment 1. Effect of insecticide-fed aphids on 2nd and 4th} instar C. maculata fitness

The tri-trophic effects of systemic insecticides on predators were evaluated in separate assays involving 2nd and 4th instar C. maculata. For each assay, C. maculata larvae were fed one of three treatments; 1) aphids reared on plants treated with a highsublethal dose of insecticide $(2.5 \mathrm{mg} / \mathrm{L}$ thiamethoxam in water), 2) aphids reared on plants treated with a low-sublethal dose of insecticide ( $1.5 \mathrm{mg} / \mathrm{L}$ thiamethoxam in water), and 3) aphids reared on untreated plants (water only). These doses of thiamethoxam (Thiamethoxam PESTANAL ${ }^{\circledR}$, Sigma-Aldrich ${ }^{\circledR}$, Product number: 37924, St. Louis, MO, USA, 63103) were determined to be sublethal using the methods described in Daniels et al. (2009).

To establish these treatments, 300 wheat plants were grown to the two-leaf stage (about $10 \mathrm{~d}$ ). At this point, each individual plant $(\mathrm{n}=100$ plants per treatment) received a $10 \mathrm{~mL}$ soil drench of an experimental solution at the base of the plant. The soil surface was then covered with $1 \mathrm{~cm}$ deep white sand (Industrial Quartz, Granusil ${ }^{\circledR}$ Lilica Fillers, Le Sueur, MN. 56058). Four hours after the soil drench, $R$. padi were placed at the base of each of the plants, and were exposed to the treatments for $24 \mathrm{~h}\left(19^{\circ} \mathrm{C}, 16: 8 \mathrm{~L}: \mathrm{D}\right)$.

After $24 \mathrm{~h}$, living $R$. padi of all life stages were removed from the plants and fed to the $C$. maculata larvae; 25 aphids were fed to each 2nd instar and 50 to each 4 th instar ( $\mathrm{n}=15$ larvae per treatment). In addition to the aphids, each larva was given a water-saturated cotton wick, and larvae were kept at $26.5{ }^{\circ} \mathrm{C}$ with a 16:8 L:D photoperiod. After $24 \mathrm{~h}$, the number of aphids remaining in each cup was counted. Fitness assessments of the larvae are described below. 


\subsubsection{Experiment 2. The effects of aphid population size on their} toxicity to 2nd instar C. maculata

Information from experiment 1 suggested that aphid densities were affecting the toxicity of the plants. This prompted us to conduct an assay exploring how increasing aphid densities affected the toxicity of thiamethoxam to aphids and lady beetles (via aphid prey). Five treatments were established that differed in aphid population size on wheat plants treated with a single dose of thiamethoxam. Plants ( $n=210$ plants) were raised in the greenhouse as above. Two-leaf stage plants $(\mathrm{n}=185)$ received $10 \mathrm{~mL}$ of $1.5 \mathrm{mg} / \mathrm{L}$ aqueous thiamethoxam solution as a soil drench. The remaining 25 plants received only water. The soil surface was then coated with white quartz sand ( $1 \mathrm{~cm}$ deep). Barring the differences in aphid densities, the experimental protocols outline above was identical to those in this experiment. Treatments varied in the number of aphids per plant: $5,10,20$ or 50 aphids were placed on the thiamethoxam-treated plants and 20 aphids were placed on the untreated control plants. Plants with aphids on them were placed in individual $0.7 \mathrm{~L}$ cups (Solo ${ }^{\circledR}$, Urbana, IL, 61801). A hole in the bottom of the cup was arranged so that the lip of the Cone-tainer ${ }^{\circledR}$ was flush with the bottom of the cup, and mesh cloth covered the top of the cup to allow airflow but prevent aphid escape. These arenas were kept at $25^{\circ} \mathrm{C}, 16: 8 \mathrm{~h} \mathrm{~L}: \mathrm{D}$, and $50 \%$ relative humidity for $24 \mathrm{~h}$. After this period, aphids from multiple plants within a designated treatment were combined prior to being fed to the C. maculata larvae. Five aphids from each of 10 plants of each treatment were saved in individual $0.5 \mathrm{~mL}$ microcentrifuge tubes and frozen at $-20{ }^{\circ} \mathrm{C}$ for later insecticide quantification. Second instars of $C$. maculata ( $\mathrm{n}=15$ per treatment) were placed individually into rearing cups (30 mL WNA Commet ${ }^{\mathrm{TM}}$, Chelmsford, MA, USA, 01824). Each cup was then provided with 25 aphids of the designated treatment, along with a water saturated cotton wick. Cups with larvae were kept for $24 \mathrm{~h}$ in a growth chamber (16:8 h $\left.\mathrm{L}: \mathrm{D} ; 26.5^{\circ} \mathrm{C}\right)$.

\subsubsection{C. maculata fitness assessments}

Following the experiments, a number of tests were performed on each larva to evaluate the effects of insecticide-fed aphids on C. maculata fitness. Larval walking speeds were measured by placing the larva on the center of a white sheet of paper, measuring the distance traveled by the larva per unit time $(\mathrm{cm} / \mathrm{s})$. The larva's path was traced using a wax crayon; this path was then measured using string and a ruler (Lundgren and Wiedenmann, 2002; Smith and Krischik, 1999). Each insect was measured three times. After mobility was measured, the larvae were given new rearing cups with a water wick and excess Lundgren's Super C. mac Diet; food and water were checked daily until pupation. The durations of each larval stadium and the remaining larval stages were recorded for each individual. Pupae were weighed to the nearest $0.1 \mathrm{mg}$, and eclosed adults were frozen upon emergence. Adult dry weight (beetles dried to a stable weight at room temperature) and beetle sex were recorded. The entire assays were repeated twice for 2 nd instars and 4th instars.

\subsection{Quantification of neonicotinoids in plants and insects}

\subsubsection{Extraction from wheat tissue}

Methods for extraction of insecticide from wheat tissue were altered slightly from Lanka et al. (2013). Wheat leaf tissue $(0.1 \mathrm{~g})$ was combined with $1 \mathrm{~mL}$ methanol and homogenized with a pestle. The homogenate was shaken for $1 \mathrm{~h}$ on an orbital shaker. The samples were then centrifuged at $10,000 \mathrm{~g}$ for $5 \mathrm{~min}$. The supernatant was dried completely at $35{ }^{\circ} \mathrm{C}$ under a stream of nitrogen gas. Dried samples were reconstituted in $600 \mu$ laboratory grade pure water containing $0.05 \%$ Triton $^{\mathrm{TM}} \mathrm{X}-100$ (Triton $^{\mathrm{TM}} \mathrm{X}-100$,
Sigma-Aldrich ${ }^{\circledR}$, Product code: 1001694711, St. Louis, MO, USA, 63103).

\subsubsection{Extraction from aphid tissue}

Five aphids from a given treatment were homogenized in $55 \mu \mathrm{l}$ methanol in a $1.5 \mathrm{~mL}$ microcentrifuge tube using a plastic pestle. Homogenate was agitated for $1 \mathrm{~h}$ on an orbital shaker. The homogenate was then centrifuged for $5 \mathrm{~min}$ at $10,000 \mathrm{~g}$. The resulting supernatant was completely dried at $35^{\circ} \mathrm{C}$ under a stream of nitrogen. The dried aphid residue was re-suspended in water containing $0.05 \%$ Triton $^{\mathrm{TM}} \mathrm{X}-100$ (Triton $^{\mathrm{TM}} \mathrm{X}-100$, Sigma-Aldrich ${ }^{\circledR}$, Product code: 1001694711, St. Louis, MO, USA, 63103). Hereafter this mixture will be referred to as $100 \%$ aphid extract.

\subsubsection{Thiamethoxam ELISA procedure}

Methods of Byrne et al. (2005) were optimized to quantify thiamethoxam in wheat tissue samples. The ELISA kit (Thiamethoxam HS plate kit, lot no. 13014E; Beacon Analytical Systems Inc., Saco, ME) had a detection range of $0.05-2.0 \mathrm{ppb}$, no matrix effects on assay results were detected in wheat (using methods from Byrne et al., 2005), and matrix effects were controlled for in the aphid assays. All ELISAs were conducted on $10 \%$ wheat extracts (diluted in E-pure filtered water to eliminate matrix effects) and 100\% aphid extracts. Two standard curves were created: one for wheat and the other for the aphid matrices. The wheat standard curve was made using 10\% extract (in water) of and un-treated wheat plant that was "spiked" with one of eight thiamethoxam dilutions: $0,0.1,0.2,0.5,1.0,2.0,4.0$ and $8.0 \mathrm{ppb}$. The aphid standard curve (100\% aphid solution) was run on untreated aphids that were spiked with $0,0.03,0.06,0.13,0.25,0.5,1.0$, and $2.0 \mathrm{ppb}$ thiamethoxam. Three replicates of each standard curve were generated. ELISAs were conducted following manufacturer's instructions, and the optical densities of all the thiamethoxam dilutions were measured at $450 \mathrm{~nm}$ using a spectrophotometer (BIO-TEK $^{\circledR} \mu$ Quant; Winooski, VT, 05404). Optical densities from each wheat and aphid sample (along with the tissue-specific standard curve) were then used to calculate the quantity of thiamethoxam per $g$ of wheat and per aphid. Assays were conducted on eight independent wheat samples per treatment from both experiments, on eight independent aphid samples per treatment from experiment 1 , and on four independent aphid samples per treatment from experiment 2 (due to sample limitations and the unanticipated requirement of using the clothianidin test for aphid tissues).

\subsubsection{Clothianidin ELISA procedures}

Thiamethoxam is converted to the metabolite clothianidin within insect tissues (Nauen et al., 2003). For this reason, aphids from experiment 2 were analyzed for clothianidin using a commercially available, competitive ELISA kit (Imidacloprid ELISA, Microtiter Plate, Product No. 500800, Abraxis LLC ${ }^{\circledR}, 54$ Steamwhistle Drive, Warminster, PA, USA, 18974). This imidacloprid kit has a high cross-reactivity to clothianidin making it a useful tool for quantifying this chemical in the absence of imidacloprid. Methods presented for the sample preparation, standard curve creation, and quantification of toxin per aphid are identical for those described in the thiamethoxam kit above.

\subsection{Data analysis}

The effects of insecticide dose on larval development time, walking speed, and size were compared among the three treatments using independent 2-way ANOVAs. Separate analyses were conducted on 2nd and 4th instars, and experimental block and treatments were included as effects in the analyses. Similarly, the 
effects of aphid density on the development, walking speed, and size of 2nd instars were compared among the five treatments using independent ANOVA (no effect of treatment block was revealed). The quantities of thiamethoxam in wheat, and clothianidin and thiamethoxam in aphids were compared among the aphid density treatments and the insecticide dose treatments using independent ANOVAs. For graphical representation, if a control treatment was calculated to have a negative quantity of insecticide the figure was adjusted so the control represents zero insecticide.

\section{Results}

\subsection{Effect of thiamethoxam dose and aphid density on toxin levels in plant and prey}

The concentration of thiamethoxam in the soil drenches were positively correlated with the thiamethoxam concentration found in wheat tissue (Fig. 1A). The level of aphid infestation on wheat plants significantly $(P=0.03)$ affected how much thiamethoxam was detected within wheat tissue (Fig. 1B). In particular, wheat that had five aphids per plant had significantly more thiamethoxam than treatments that had greater aphid infestations. Thiamethoxam
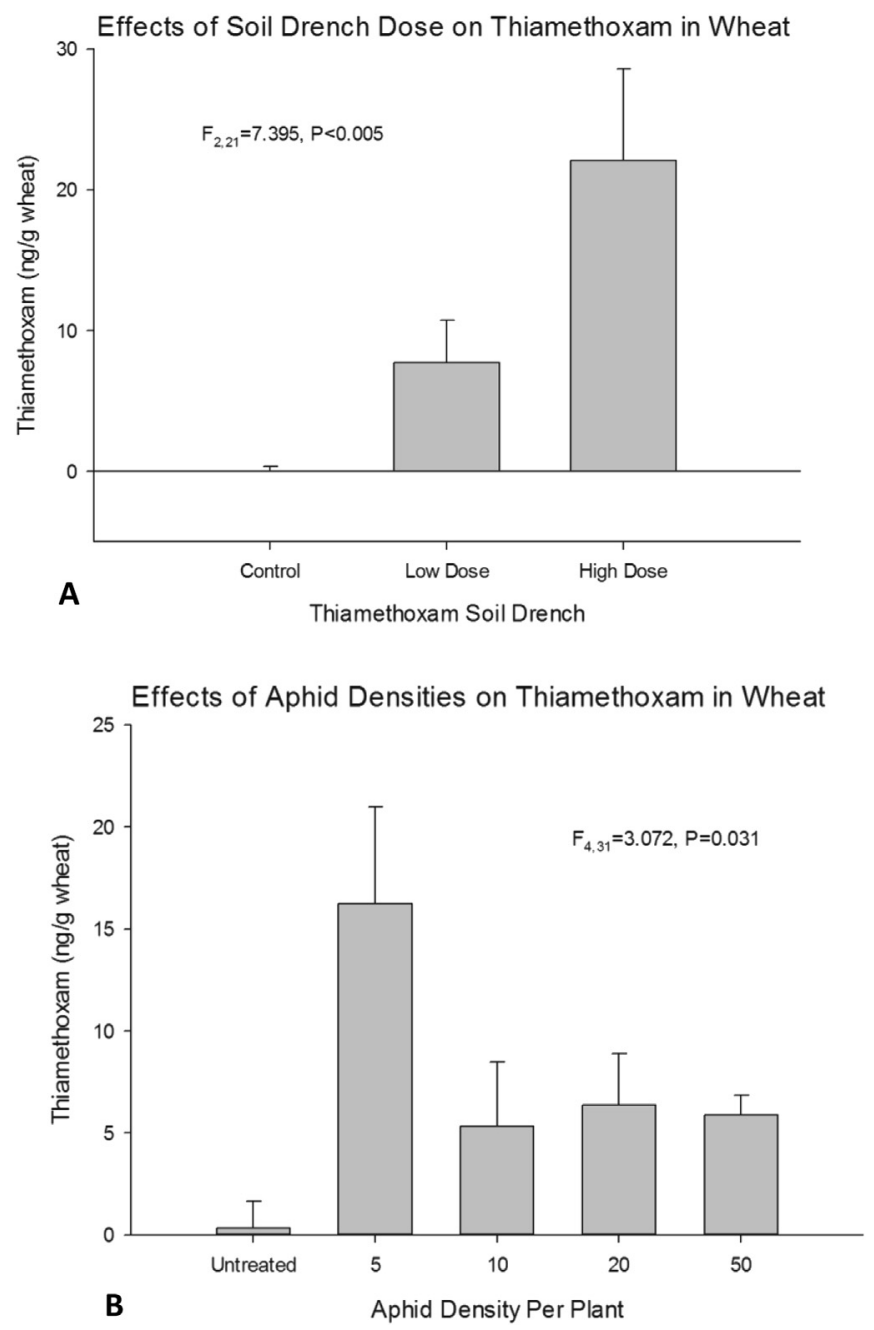

Fig. 1. Thiamethoxam levels in wheat A) using different concentrations of soil drench $(10 \mathrm{~mL}$ of $1.5 \mathrm{mg} / \mathrm{mL}$ and $2.5 \mathrm{mg} / \mathrm{mL}$ for low-sublethal and high-sublethal doses, respectively), and B) when a single concentration ( $10 \mathrm{~mL}$ of $1.5 \mathrm{mg} / \mathrm{mL}$ ) of soil drench was applied, but different aphid densities were placed on the plants. was undetectable in aphids, but clothianidin was found in aphids feeding on treated plants. There was not an effect of aphid density on the dose of clothianidin found per aphid (pooled across treatments, $0.00058 \pm 0.0037 \mathrm{ng}$ clothianidin/aphid, $\mathrm{F}_{4,14}=2.67$, $P=0.08$ )

\subsection{Effect of thiamethoxam dose on aphid toxicity/quality for 2nd instar lady beetles}

There was a significant effect of dietary treatment on the fitness parameters displayed by 2 nd instar $C$. maculata, although there were substantial differences in our results between the two experimental blocks (Table 1). The significant treatment effects in larval duration were almost entirely driven by differences in the duration of the 2nd stadium (diet: $F_{2}, 78=5.50, P=0.01$; block: $F_{1}$, $78=4.14, P=0.05$; interaction: $F_{2}, 78=8.00, P=0.001$ ). Specifically, 2nd stadium duration was significantly reduced in the lowsublethal dose treatment compared to the no-insecticide treatment; the high-sublethal dose was statistically indistinguishable from the other two treatments (Table 1). Only two of the C. maculata died when fed untreated aphids; the low-sublethal dose treatment had five deaths, high-sublethal dose had four deaths and unfed treatment (unfed for the $24 \mathrm{~h}$ aphid exposure) had five deaths from the time of aphid consumption until pupation.

\subsection{Effect of aphid density on thiamethoxam toxicity to 2nd instar lady beetles}

Experiment 1 was separated into two blocks because of resource limitations; although every effort was made to keep the methods in these blocks identical, one major (and unintentional) difference between the two experimental blocks was the number of aphids that were infested onto the wheat plants. This block effect caused a major discrepancy in the results; the first block with less crowded aphids had a much stronger negative treatment effect of the aphids on C. maculata 2 nd instars. This prompted the authors to perform experiment 2 to analyze whether or not the density of aphids on treated wheat plants altered the aphid's quality as prey for the 2nd instar C. maculata.

C. maculata larval fitness improved when they were fed aphids that were crowded on wheat plants containing a standard dose of insecticide. There were no significant effects of aphid crowding on aphid consumption $\left(F_{4}, 70=0.47, P=0.76\right)$, on the duration of the 2nd stadium $\left(\mathrm{F}_{4,64}=1.13, P=0.35\right)$, on larval and pupal combined duration $\left(F_{4}, 59=2.25, P=0.07\right)$ or on pupal weight $\left(F_{4}, 60=1.81\right.$, $P=0.14)$. However, C. maculata 2 nd instars walked faster when larvae consumed aphids that were more crowded on the insecticide-treated plants $\left(F_{4,67}=3.16, P=0.02\right)$ (Fig. 2). Specifically, the larvae fed aphids from the treatment with five aphids per plant had significantly slower walking speeds than those larvae from the control, 10, 20 and 50 aphids per plant treatments (Fig. 2).

\subsection{Effect of thiamethoxam dose on aphid toxicity/quality for 4th instar lady beetles}

All of the 4th instar lady beetles consumed the 50 aphids given to them over the $24 \mathrm{~h}$ period. There was no effects of dietary treatment on 4th instar response variables measured here (Table 2). There was an effect of experimental block on the combined duration of the 4th stadium and pupal stage (the first block developed faster than the second, block: $F_{1}, 76=19.63, P<0.001$ ), but no interaction between block and dietary treatment was observed in 4 th instar beetles as was in 2 nd instars (Table 2 ). 
Table 1

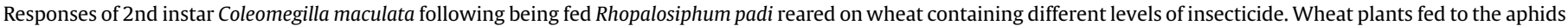

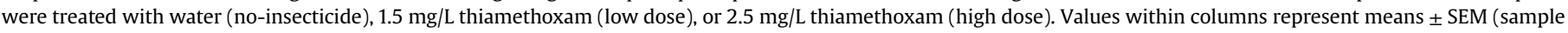
size). Within a column, rows followed by different capital letters are significantly different from one another (Fisher's LSD test, $\alpha=0.05$ ).

\begin{tabular}{|c|c|c|c|c|c|}
\hline Treatment & Aphids eaten & $\begin{array}{l}\text { Larval duration } \\
\text { (2nd-4th stadia; d) }\end{array}$ & Pupal weight (mg) & $\begin{array}{l}\text { Head capsule width } \\
\text { (3rd instars; mm) }\end{array}$ & Walking speed $(\mathrm{cm} / \mathrm{s})$ \\
\hline No insecticide & $\begin{array}{l}10.30 \pm 0.61(27) \\
A\end{array}$ & $\begin{array}{l}8.57 \pm 0.25(28) \\
A\end{array}$ & $14.25 \pm 0.33(28)$ & $1.38 \pm 0.01(28)$ & $0.85 \pm 0.05(29)$ \\
\hline Low dose & $\begin{array}{l}16.15 \pm 0.89(26) \\
B\end{array}$ & $\begin{array}{l}7.96 \pm 0.22(25) \\
\text { B }\end{array}$ & $14.13 \pm 0.29(24)$ & $1.38 \pm 0.02(22)$ & $0.86 \pm 0.08(28)$ \\
\hline High dose & $\begin{array}{l}15.31 \pm 1.06(29) \\
\mathrm{B}\end{array}$ & $\begin{array}{l}8.23 \pm 0.26(26) \\
A B\end{array}$ & $14.13 \pm 0.43(26)$ & $1.40 \pm 0.01(25)$ & $0.98 \pm 0.05(29)$ \\
\hline ANOVA results & $\begin{array}{l}\text { Diet: } \\
\mathrm{F}_{2,76}=17.40, \\
P<0.001 \\
\text { Block: } \\
\mathrm{F}_{1,76}=17.25, \\
P<0.001 ; \\
\text { Interaction: } \mathrm{F}_{2,76}=11.31, \\
P<0.001\end{array}$ & $\begin{array}{l}\text { Diet: } \\
\mathrm{F}_{2,73}=2.89 \\
P=0.01 \\
\text { Block: } \\
\mathrm{F}_{1,73}=85.64 \\
P<0.001 \\
\text { Interaction: } \mathrm{F}_{2,73}=0.66 \\
P=0.52\end{array}$ & $\begin{array}{l}\text { Diet: } \\
\mathrm{F}_{2,72}=0.02 \\
P=0.98 \\
\text { Block: } \\
\mathrm{F}_{1}, 72=0.07 \\
P=0.80 \\
\text { Interaction: } \mathrm{F}_{2,72}=0.55 \\
P=0.58\end{array}$ & $\begin{array}{l}\text { Diet: } \\
\mathrm{F}_{2,69}=1.42 \\
P=0.25 \\
\text { Block: } \\
\mathrm{F}_{1,69}=13.09 \\
P=0.001 \\
\text { Interaction: } \mathrm{F}_{2,69}=3.00 \\
P=0.06\end{array}$ & $\begin{array}{l}\text { Diet: } \\
\mathrm{F}_{2,80}=2.19 \\
P=0.12 \\
\text { Block: } \\
\mathrm{F}_{1,80}=16.27 \\
P<0.001 \\
\text { Interaction: } \mathrm{F}_{2,80}=7.36 \\
P=0.001\end{array}$ \\
\hline
\end{tabular}

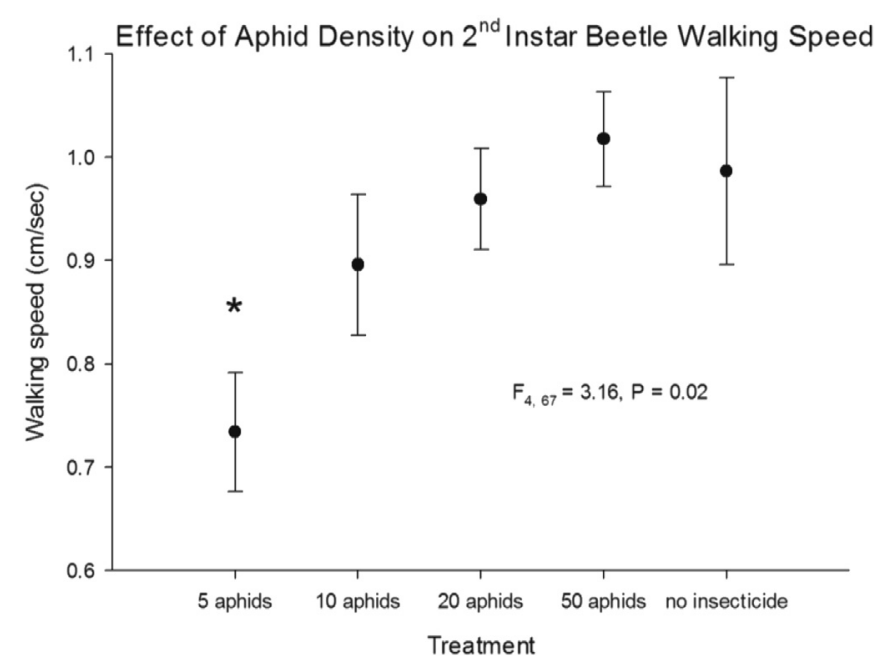

Fig. 2. The walking speeds of Coleomegilla maculata after they had fed upon aphids that had been reared on plants with a consistent thiamethoxam soil drench concentration $(1.5 \mathrm{mg} / \mathrm{L})$ but varying aphid densities.

\section{Discussion}

Our study revealed that herbivore density interacts with systemic neonicotinoid insecticides in ways that may affect higher trophic levels responsible for regulating pest insect populations. Aphids fed wheat treated with sub-lethal doses of thiamethoxam had a measurable adverse, prey-mediated effects on the fitness of young lady beetle larvae, but only when aphids were less crowded on the plants. Aphid density had an effect on the amount of insecticide detectable within the plants as well. Additional tests under field conditions will be necessary to substantiate whether the observed interactions of aphids and thiamethoxam quantity are manifested in the field, and whether observed toxicity to C. maculata will affect their populations or function under realistic conditions.

Younger $C$. maculata larvae were affected more than older larvae by the aphids fed differing insecticide doses. The 4th instars were resilient to the varying treatments in experiment 1 and there were no negative effects observed in the older $C$. maculata larvae that consumed aphids from the plants treated with different insecticide doses. For this reason, the 4th instar beetles were not used in experiment 2 . Older and larger larvae often are more resilient to insecticide treatments (Nauen et al., 2008). In contrast to the 4th instars, there were differences between treatments in the life history characteristics of 2 nd instar C. maculata. Although not significant, the mortality of 2 nd instars in response to insecticide dose suggests that the more concentrated the insecticidal drench, the risk of death increases. The 2nd instars ate significantly fewer untreated aphids than the two treated groups of aphids. This consumption level may have resulted if the affected aphids experienced reduced mobility or lowered defensive capabilities making them easy targets for lady beetles. Provost et al. (2006) found that the predatory ladybeetle Harmonia axyridis preferred immobilized prey, even if the prey was of less nutritional quality than active prey. Another possibility is that the aphids on the untreated plants were larger and thus represented a larger meal (although this was not measured in our study), and this difference in prey quality could certainly affect predator consumption rates.

Aphid density had a clear effect on their toxicity or quality for this predator. Walking speeds of beetles decreased as aphid density on wheat plants decreased (Table 3); beetles that consumed the least crowded aphids were significantly slower than the rest (Fig. 2). Wheat plants with the lowest aphid density had significantly higher levels of thiamethoxam within their tissues compared to wheat plants with higher aphid densities (Fig. 1B). No clear trends in the content of clothianidin per aphid were evident, suggesting that this least crowded aphid treatment did not give a higher dose to the predators than the others. Thus, we hypothesize that the quality of aphids in the 5-aphid density was lower, but these were not more toxic to the predators. The question of why the wheat plants with low aphid densities had higher concentrations of thiamethoxam than those plants with more severe aphid infestations deserves more attention. Previous research has shown that herbivory of insects on a plant can cause large shifts in metabolic activity of the plant (Szczepaniec et al., 2013). For example, Helicoverpa zea feeding on a tomato plant alters the concentrations of compounds related to plant defenses (Steinbrenner et al., 2011). In another case, aphid feeding was shown to alter gene function drastically in a host plant, manipulating the production of mRNA, ultimately leading to changed protein levels and plant metabolism (Moran and Thompson, 2001). It might be possible that when aphid density on wheat plants increases, a threshold is reached by which plant metabolism changes and ultimately neonicotinoid concentration is decreased.

In the current study there was clothianidin, but no thiamethoxam, detected within aphids. This finding is consistent with previous work done using High Performance Liquid 
Table 2

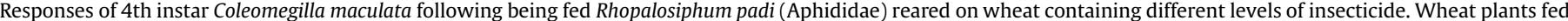

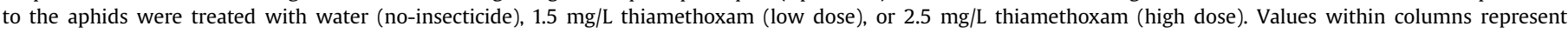
means \pm SEM (sample size).

\begin{tabular}{|c|c|c|c|c|}
\hline Treatment & Preimaginal development (d) & Adult dry weight (mg) & Walking speed $(\mathrm{cm} / \mathrm{s})$ & Sex ratio (prop male) \\
\hline No insecticide & $7.54 \pm 0.31(28)$ & $2.56 \pm 0.06(27)$ & $2.68 \pm 0.11(29)$ & $0.708(24)$ \\
\hline Low dose & $7.69 \pm 0.19(26)$ & $2.55 \pm 0.05(26)$ & $2.68 \pm 0.10(28)$ & $0.577(26)$ \\
\hline High dose & $7.79 \pm 0.17(28)$ & $2.45 \pm 0.06(28)$ & $2.76 \pm 0.08(30)$ & $0.679(28)$ \\
\hline \multirow[t]{9}{*}{ Statistical comparison (ANOVA) } & Diet: & Diet: & Diet: & \\
\hline & $\mathrm{F}_{2,76}=0.33$ & $\mathrm{~F}_{2,75}=1.19$ & $\mathrm{~F}_{2,81}=1.02$ & \\
\hline & $\mathrm{P}=0.72$ & $\mathrm{P}=0.31$ & $\mathrm{P}=0.37$ & \\
\hline & Block: & Block: & Block: & \\
\hline & $F_{1,76}=19.63$ & $\mathrm{~F}_{1,75}=0.17$ & $\mathrm{~F}_{1,81}=2.20$ & \\
\hline & $\mathrm{P}<0.001$ & $P=0.68$ & $\mathrm{P}=0.14$ & \\
\hline & Interaction: & Interaction: & Interaction: & \\
\hline & $\mathrm{F}_{2,76}=0.56$ & $\mathrm{~F}_{2,75}=0.27$ & $\mathrm{~F}_{2,81}=1.12$ & \\
\hline & $\mathrm{P}=0.58$ & $P=0.77$ & $\mathrm{P}=0.33$ & \\
\hline
\end{tabular}

Table 3

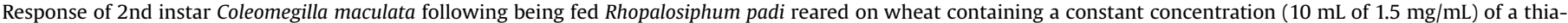
methoxam soil drench, but differing densities of aphids.

\begin{tabular}{|c|c|c|c|c|c|}
\hline Treatment & Aphids consumed & 2nd instar duration (days) & Larval + pupae duration (days) & Pupal weight (mg) & Walking speed $(\mathrm{cm} / \mathrm{sec})$ \\
\hline 5 aphids & $18.13 \pm 1.13(15)$ & $1.27 \pm 0.15(15)$ & $11.43 \pm 0.27(14)$ & $13.86 \pm 0.50(14)$ & $0.73 \pm 0.06(14)$ \\
\hline 10 aphids & $17.53 \pm 0.10(15)$ & $1.20 \pm 0.11(15)$ & $10.8 \pm 0.14(15)$ & $14.74 \pm 0.34(15)$ & $0.90 \pm 0.07(15)$ \\
\hline 20 aphids & $17.40 \pm 1.25(15)$ & $1.08 \pm 0.08(13)$ & $11.36 \pm 0.24(11)$ & $14.55 \pm 0.43(11)$ & $0.96 \pm 0.05(15)$ \\
\hline 50 aphids & $16.2 \pm 0.82(15)$ & $1.00 \pm 0.00(13)$ & $10.85 \pm 0.15(11)$ & $15.29 \pm 0.40(14)$ & $1.02 \pm 0.05(15)$ \\
\hline 20 aphids with no insecticide & $17.93 \pm 1.28(15)$ & $1.25 \pm 0.13(12)$ & $11.18 \pm 0.12(11)$ & $13.97 \pm 0.40(11)$ & $0.99 \pm 0.05(13)$ \\
\hline \multirow[t]{2}{*}{ Statistical comparison (ANOVA) } & Diet: & Diet: & Diet: & Diet: & Diet: \\
\hline & $\begin{array}{l}F_{4,70}=0.47 \\
P=0.76\end{array}$ & $\begin{array}{l}F_{4,64}=1.13 \\
P=0.35\end{array}$ & $\begin{array}{l}F_{4,59}=2.25 \\
P=0.07\end{array}$ & $\begin{array}{l}\mathrm{F}_{4,60}=1.81 \\
\mathrm{P}=0.14\end{array}$ & $\begin{array}{l}\mathrm{F}_{4,67}=3.16 \\
\mathrm{P}=0.02\end{array}$ \\
\hline
\end{tabular}

Chromatography to observe the metabolic breakdown of thiamethoxam into clothianidin within the tissues of plants (Nauen et al., 2003) and insects (Benzidane et al., 2010; Nauen et al., 2003). These studies raise a noteworthy issue within toxicological studies; the metabolites of neonicotinoid insecticides can be abundant in agroecosystems and in some cases are more effective at eliciting toxic responses than the active ingredient of the product initially applied. For example, a study comparing thiamethoxam and clothianidin (thiamethoxam's main breakdown metabolite) showed higher toxicity of clothianidin to Periplaneta americana (L.) (Blattodea: Blattidae) (Benzidane et al., 2010). The future of non-target risk assessments and insecticidal fate research must take into consideration the breakdown products of an insecticide and whether or not they pose a risk to beneficial insects.

\section{Acknowledgments}

The authors would like to thank Janet Fergen, Ryan Schmid, Megan Wentzel and Mallory Wentzel for assistance in the laboratory. Helpful advice was given by Frank Byrne in synthesizing an ELISA protocol. Mention of proprietary products does not constitute endorsement by the USDA.

\section{References}

Benzidane, Y., Communal, P.Y., Leduc, L., Thany, S.H., Touinsi, S., Motte, E. Jadas-Hécart, A., 2010. Effect of thiamethoxam on cockroach locomotor activity is associated with its metabolite clothianidin. Pest Manag. Sci. 66, 1351-1359.

Biddinger, D.J., Weber, D.C., Hull, L.A., 2009. Coccinellidae as predators of mites: Stethorini in biological control. Biol. Control 51, 268-283.

Birch, A.N.E., Hackett, C.A., Gatehouse, A.M.R., Gatehouse, J.A., Geoghegan, I.E., Majerus, M.E.N., McNicol, J.W., 1999. Tri-trophic interactions involving pest aphids, predatory 2-spot ladybirds and transgenic potatoes expressing snowdrop lectin for aphid resistance. Mol. Breed. New Strateg. Plant Improv. 5, $75-83$.
Byrne, F.J., Toscano, N.C., Urena, A.A., Morse, J.G., 2005. Quantification of imidacloprid toxicity to avocado thrips, Scirtothrips perseae Nakahara (Thysanoptera: Thripidae), using a combined bioassay and ELISA approach. Pest Manag. Sci. 61, 754-758.

Cowles, R.S., Montgomery, M.E., Cheah, C.A.S.J., 2006. Activity and residues of imidacloprid applied to soil and tree trunks to control hemlock woolly Adelgid (Hemiptera: Adelgidae) in forests. J. Econ. Entomol. 99, 1258-1267.

Cresswell, J., 2011. A meta-analysis of experiments testing the effects of a neonicotinoid insecticide (imidacloprid) on honey bees. Ecotoxicology 20 149-157.

Daniels, M., Bale, J.S., Newbury, H.J., Lind, R.J., Pritchard, J., 2009. A sublethal dose of thiamethoxam causes a reduction in xylem feeding by the bird cherry-oat aphid (Rhopalosiphum padi), which is associated with dehydration and reduced performance. J. Insect Physiol. 55, 758-765.

Dively, G.P., Kamel, A., 2012. Insecticide residues in pollen and nectar of a cucurbit crop and their potential exposure to pollinators. J. Agric. Food Chem. 60, 4449-4456.

Dryden, M.W., Payne, P.A., Vicki, S., Riggs, B., Davenport, J., Kobuszewski, D., 2011 Efficacy of dinotefuran-pyriproxyfen, dinotefuran-pyriproxyfen-permethrin and fipronil-(S)-methoprene topical spot-on formulations to control flea populations in naturally infested pets and private residences in Tampa, FL. Vet. Parasitol. 182, 281-286.

Dutton, A., Klein, H., Romeis, J., Bigler, F., 2002. Uptake of Bt-toxin by herbivores feeding on transgenic maize and consequences for the predator Chrysoperla carnea. Ecol. Entomol. 27, 441-447.

Elliott, N., Kieckhefer, R., Lee, J.-H., French, B., 1999. Influence of within-field and landscape factors on aphid predator populations in wheat. Landsc. Ecol. 14 239-252.

Fischer, J., Müller, T., Spatz, A.-K., Greggers, U., Grünewald, B., Menzel, R., 2014. Neonicotinoids interfere with specific components of navigation in honeybees. PLos One 9, e91364.

Girolami, V., Mazzon, L., Squartini, A., Mori, N., Marzaro, M., Bernardo, A.D., Greatti, M., Giorio, C., Tapparo, A., 2009. Translocation of neonicotinoid insecticides from coated seeds to seedling guttation drops: a novel way of intoxication for bees. J. Econ. Entomol. 102, 1808-1815.

Gray, S.M., Bergstrom, G.C., Vaughan, R., Smith, D.M., Kalb, D.W., 1996. Insecticidal control of cereal aphids and its impact on the epidemiology of the barley yellow dwarf luteoviruses. Crop Prot. 15, 687-697.

Grewal, P.S., Shetlar, D.J., Power, K.T., 2001. Neonicotinoid insecticides alter diapause behavior and survival of overwintering white grubs (Coleoptera: Scarabaeidae). Pest Manag. Sci. 57, 852-857.

Iwasa, T., Motoyama, N., Ambrose, J.T., Roe, R.M., 2004. Mechanism for the differential toxicity of neonicotinoid insecticides in the honey bee, Apis mellifera. Crop Prot. 23, 371-378. 
Jeschke, P., Nauen, R., Beck, M.E., 2013. Nicotinic acetylcholine receptor agonists: a milestone for modern crop protection. Angew. Chem. Int. Ed. Engl. 52, 9464-9485.

Jeschke, P., Nauen, R., Schindler, M., Elbert, A., 2010. Overview of the status and global strategy for neonicotinoids. J. Agric. Food Chem. 59, 2897-2908.

Jiménez-Martínez, E.S., Bosque-Pérez, N.A., Berger, P.H., Zemetra, R.S., 2004. Life history of the bird cherry-oat aphid, Rhopalosiphum padi (Homoptera: Aphididae), on transgenic and untransformed wheat challenged with barley yellow dwarf virus. J. Econ. Entomol. 97, 203-212.

Juraske, R., Castells, F., Vijay, A., Muñoz, P., Antón, A., 2009. Uptake and persistence of pesticides in plants: measurements and model estimates for imidacloprid after foliar and soil application. J. Hazard. Mater. 165, 683-689.

Krischik, V.A., Landmark, A.L., Heimpel, G.E., 2007. Soil-applied imidacloprid is translocated to nectar and kills nectar-feeding Anagyrus pseudococci (Girault) (Hymenoptera: Encyrtidae). Environ. Entomol. 36, 1238-1245.

Lanka, S.K., Ottea, J.A., Davis, J.A., Hernandez, A.B., Stout, M.J., 2013. Systemic effects of thiamethoxam and chlorantraniliprole seed treatments on adult Lissorhoptrus oryzophilus (Coleoptera: Curculionidae) in rice. Pest Manag. Sci. 69, $250-256$.

Lanka, S.K., Stout, M.J., Ottea, J.A., 2014. Evaluation of neonicotinoids as pyrethroid alternatives for rice water weevil management in water-seeded rice. Crop Prot. $56,37-43$.

Lundgren, J.G., 2009. Relationships of natural enemies and non-prey foods. In: Lundgren, Jonathan G. (Ed.), Progress in Biological Control, vol. 7. Springer, Dordrecht.

Lundgren, J.G., Moser, S.E., Hellmich, R.L., Seagraves, M.P., 2011. The effects of diet on herbivory by a predaceous lady beetle. Biocontrol Sci. Technol. 21, 71-74.

Lundgren, J.G., Wiedenmann, R.N., 2002. Coleopteran-specific Cry3Bb toxin from transgenic corn pollen does not affect the fitness of a nontarget species, Coleomegilla maculata DeGeer (Coleoptera: Coccinellidae). Environ. Entomol. 31, 1213-1218.

Lundgren, J.G., Wiedenmann, R.N., 2005. Tritrophic interactions among Bt (Cry3Bb1) corn, aphid prey, and the predator Coleomegilla maculata (Coleoptera: Coccinellidae). Environ. Entomol. 34, 1621-1625.

Magalhaes, L.C., Hunt, T.E., Siegfried, B.D., 2009. Efficacy of neonicotinoid seed treatments to reduce soybean aphid populations under field and controlled conditions in Nebraska. J. Econ. Entomol. 102, 187-195.

Maienfisch, P., Angst, M., Brandl, F., Fischer, W., Hofer, D., Kayser, H., Kobel, W., Rindlisbacher, A., Senn, R., Steinemann, A., Widmer, H., 2001. Chemistry and biology of thiamethoxam: a second generation neonicotinoid. Pest Manag. Sci. 57, 906-913.

McCornack, B.P., Ragsdale, D.W., 2006. Efficacy of Thiamethoxam to Suppress Soybean Aphid Populations in Minnesota Soybean. Crop Management (online) (doi:10/1094/CM-2006-0915-01-RS).

Moran, P.J., Thompson, G.A., 2001. Molecular responses to aphid feeding in Arabidopsis in relation to plant defense pathways. Plant Physiol. 125, 1074-1085.

Moser, S.E., Obrycki, J.J., 2009. Non-target effects of neonicotinoid seed treatments; mortality of coccinellid larvae related to zoophytophagy. Biol. Control 51, 487-492.

[NASS] National Agricultural Statistics Service, 2014. Quick Stats. US Department of Agriculture, NASS, Washington (DC), 12 July 2014. http://quickstats.nass.usda. gov/results/CBC2D149-CF7B-396F-A665-825E4825B1A7?pivot=short_desc.
Nauen, R., Bielza, P., Denholm, I., Gorman, K., 2008. Age-specific expression of resistance to a neonicotinoid insecticide in the whitefly Bemisia tabaci. Pest Manag. Sci. 64, 1106-1110.

Nauen, R., Denholm, I., 2005. Resistance of insect pests to neonicotinoid insecticides: current status and future prospects. Arch. Insect Biochem. 58, 200-215.

Nauen, R., Ebbinghaus-Kintscher, U., Salgado, V.L., Kaussmann, M., 2003. Thiamethoxam is a neonicotinoid precursor converted to clothianidin in insects and plants. Pestic. Biochem. Physiol. 76, 55-69.

Obrycki, J.J., Harwood, J.D., Kring, T.J., O'Neil, R.J., 2009. Aphidophagy by Coccinellidae: application of biological control in agroecosystems. Biol. Control 51, 244-254.

Provost, C., Lucas, É., Coderre, D., Chouinard, G., 2006. Prey selection by the lady beetle Harmonia axyridis: the influence of prey mobility and prey species. J. Insect Behav. 19, 265-277.

Rogers, M.A., Krischik, V.A., Martin, L.A., 2007. Effect of soil application of imidacloprid on survival of adult green lacewing, Chrysoperla carnea (Neuroptera: Chrysopidae), used for biological control in greenhouse. Biol. Control 42, 172-177.

Schneider, C.W., Tautz, J., Grünewald, B., Fuchs, S., 2012. RFID tracking of sublethat effects of two neonicotinoid insecticides on the foraging behavior of Apis mellifera. PLoS One 7, e30023.

Scholer, J. Krischik, V. 2014. Chronic exposure of imidacloprid and clothianidin reduce queen survival, foraging, and nectar storing in colonies of Bombus impatiens. PLoS One 9, e91573.

Seagraves, M., Lundgren, J., 2012. Effects of neonicitinoid seed treatments on soybean aphid and its natural enemies. J. Pest Sci. 85, 125-132.

Shi, X., Jiang, L., Wang, H., Qiao, K., Wang, D., Wang, K., 2011. Toxicities and subletha effects of seven neonicotinoid insecticides on survival, growth and reproduction of imidacloprid-resistant cotton aphid, Aphis gossypii. Pest Manag. Sci. 67, $1528-1533$.

Smith, S.F., Krischik, V.A., 1999. Effects of systemic imidacloprid on Coleomegilla maculata (Coleoptera: Coccinellidae). Environ. Entomol. 28, 1189-1195.

Stapel, J.O., Cortesero, A.M., Lewis, W.J., 2000. Disruptive sublethal effects of in secticides on biological control: altered foraging ability and life span of a parasitoid after feeding on extrafloral nectar of cotton treated with systemic insecticides. Biol. Control 17, 243-249.

Steinbrenner, A.D., Fernie, A.R., Orians, C.M., Gómez, S., Osorio, S., 2011. Herbivoreinduced changes in tomato (Solanum lycopersicum) primary metabolism: a whole plant perspective. J. Chem. Ecol. 37, 1294-1303.

Stoner, K.A., Eitzer, B.D., 2012. Movement of soil-applied imidacloprid and thiamethoxam into nectar and pollen of squash (Cucurbita pepo). PLoS One 7, e39114.

Szczepaniec, A., Raupp, M.J., Parker, R.D., Kerns, D., Eubanks, M.D., 2013. Neonicotinoid insecticides alter induced defenses and increase susceptibility to spider mites in distantly related crop plants. PLoS One 8, e62620.

Weber, D.C., Lundgren, J.G., 2009. Assessing the trophic ecology of the Coccinellidae: their roles as predators and as prey. Biol. Control 51, 199-214.

Zhang, W., Swinton, S.M., 2009. Incorporating natural enemies in an economic threshold for dynamically optimal pest management. Ecol. Model 220 $1315-1324$ 